
\title{
Sánchez

\section{Pathos in Catalonia: the politics of images in the era of memes}

This article focuses on the study of two contextualized images within Catalonia's process of independence in order to analyze the role of the visual tradition in contemporary political scenarios. The presence of emotions and pathos in some symbolic images linked with the October 1 referendum brings up to date the intellectual legacy of Aby Warburg and his notion of Pathosformel, as applied to the study of contemporary visual culture and Internet memes.

\author{
Keywords \\ PATHOS \\ REFERENDUM \\ EMOTIONS \\ ABY WARBURG \\ CATALONIA \\ MEME
}

Date of reception: 01/05/2018

Date of acceptance: 10/10/2018

Luis Vives-Ferrándiz Sánchez Doctor in Art History from the Universitat de València, where he currently works as a teacher and researcher. His main lines of research focus on the topic of vanitas in the sphere of baroque culture, as well as his expansion on the field of contemporary visual culture under the perspective of the neo-baroque. He has also carried out studies on theoretical reflections on the image and visual culture in postmodernism, and the way in which they affect the practice of the History of Art. His most recent research has explored the use of the photographic image as an ideological and identity element, the study of new scopic regimes and contemporary iconoclasm. 
I can taste the fear

Lift me up and take me out of here

Don't want to fight, don't want to die Just want to hear you cry.

Arcade Fire, Intervention

\section{October 1st 2017}

What has become known as Catalonia's constituent process, abbreviated in Catalan as the procés, refers to the political actions aimed at achieving self-determination. Its more immediate origins are found in the desire for greater self-government in Catalonia that was expressed in its 2006 Estatut d'Autonomia (Statute of Autonomy). However, in 2010 the Tribunal Constitucional (Constitutional Court of Spain) declared a series of articles in this document to be unconstitutional. This judgement prompted the acceleration of the self-determination process, since it went from calling for self-government within the framework of Spain as a nation to demands for an independent state that would fulfill the historical national aspirations of Catalonia'. One of the most important events in the procés was when a referendum was held on October 1st 2017 that was designed to endorse the route towards independence, and which has been one of the most heated points in the Catalan crisis, given that it was declared illegal by the Spanish Government. In this context, analysts talk about a pro-independence or pro-sovereignist group that supports the different events, plebiscites, and referendums in favor of independence in Catalonia's transition to nationhood (FORTI, GONZÁLEZ I VILLALTA, UCELAYDA CAL, 2017: 3-6), against which there are the unionist or constitutionalist groups that defend Catalonia's presence in Spain, maintaining existing levels of self-government and the application of constituent legality
(SÁNCHEZ-CUENCA 2018; CANO BUESO, 2017).

The referendum, as well as the different episodes that have shaped the procés (and which still do), have brought with them images that are official or alternative, journalistic or amateur, propagandistic or counternarrative and which make up its visual culture. The purpose of this article is to study two images linked directly to the October 1st referendum that show a kind of gesturality and represent an emotion that updates the pathos formulas that were defined and studied by Aby Warburg. Therefore, this article intends to bring up-todate the meaning of these formulas in a political contemporary event and to help us understand the depth and complexity of the visual culture that developed around the political images of the procés. On the one hand, there is a photograph by photojournalist Iván Alvarado, from the Reuters agency and published in the press, which shows the reactions of people who witnessed the brief proclamation of the Republic of Catalonia after the voting results and, on the other hand, the video Help Catalonia disseminated by Òmnium Cultural on various platforms to denounce the excess force used by the national police when it came to stopping the referendum. In addition, these images were reformulated and turned into memes that circulated on the Internet with the intention of generating new meanings from the gesturality they contain. The article also studies the link between memes on the Internet, gesturality and the problematic of the pathos formulas based on the concept of memory.

\section{Iconomachy 2.0}

A lot of contemporary political conflicts live and develop as a war of images (MITCHELL, 2013) in which their control and spread (or even censorship) 
is key to the transmission of ideas, values, and concepts. The expression "war of images" is purely metaphorical and describes the wide, diverse array of images that are taken from the history of art and different visual traditions to express and compare political views in any conflict. In the case of the procés, it should be pointed out that certain iconic war images have been used by the media in order to explain what happened in Catalonia on the day of the referendum. For instance, Martin Rowson, a cartoonist for The Guardian, understood that the procés might lead to real warring conflict, and published a cartoon inspired by Premonition of Civil War (Premonición de la Guerra Civil) by Salvador Dalí in which Rajoy and Puigdemont are the combative protagonists ${ }^{2}$. On the other hand, the cartoonist Blower, in The Telegraph newspaper, made use of the famous Gerda Taro and Robert Capa photograph of The Falling Soldier (Muerte de un miliciano) to illustrate the excessive police force used on referendum day on October 1st by placing Federico Borrell in front of a group of riot police ${ }^{3}$. The Australian Financial Review cartoonist, David Rowe, opted to adapt Goya's Saturn Devouring His Sons (Saturno devorando a sus hijos) (Fig. 1), while replacing the God with a large national police officer who is about to eat a woman wearing a pro-independence Catalan flag ${ }^{4}$. Goya also served as the inspiration for Ferran Martín (El Jueves magazine), who used Fight with Cudgels (Duelo a garrotazos) to portray the violence that took place during the October 1st referendum, though changing the characters to a police officer armed with a baton and a citizen lifting a ballot box to vote ${ }^{5}$.

These examples are established in Spain's visual, cultural and identity history, and they are invoked by the artists because they are symbolic, easily recognizable examples and because they act as rhetorical frameworks that can be adapted to depict a contemporary event. Their reuse shows that the images, as a result of the visual twist of postmodernism, and regardless of their nature (artistic, documentary, journalistic...), perform an epistemological role that is based on their ability to act as agents that can shape meaning, based on their own symbolic rationale (BOEHM, 2011: 87106). Besides, in these aforementioned examples, the past is used to give meaning to the present in an exercise in history that attempts to build a link between the two periods. The past images act as interlocutors for our problems (BAL, 2016). Thus, Goya's, Capa's or Dalî's works are summoned up as ventriloquist dolls which are made to speak about a contemporary event based on the epistemological potential that these images possess.

Additionally, the procés has taken place within a complex media scenario in which images from the press, the media or the official propaganda share a space in the heterogeneous conglomerate of images that are created, shared and spread on platforms such as Facebook, Twitter, YouTube, Instagram or WhatsApp, and which define what is known as the web 2.0. The main trait of web 2.0 is that the users of these platforms are able to generate contents that are spread and popularized until they become viral (MARTíN, 2012). With web 2.0, users can either create comical, satirical or condemnatory images related to the procés and proliferate them in the form of memes, or distribute the ones that have already been put into circulation. Therefore, web 2.0 is a (metaphorical) battlefield since it can be used to express and transmit the different political viewpoints in play in the Catalan crisis. This ensemble of images, which is extremely heterogeneous and, at the same time, hard to control and study due to its breadth and brief existence, makes up what is known 


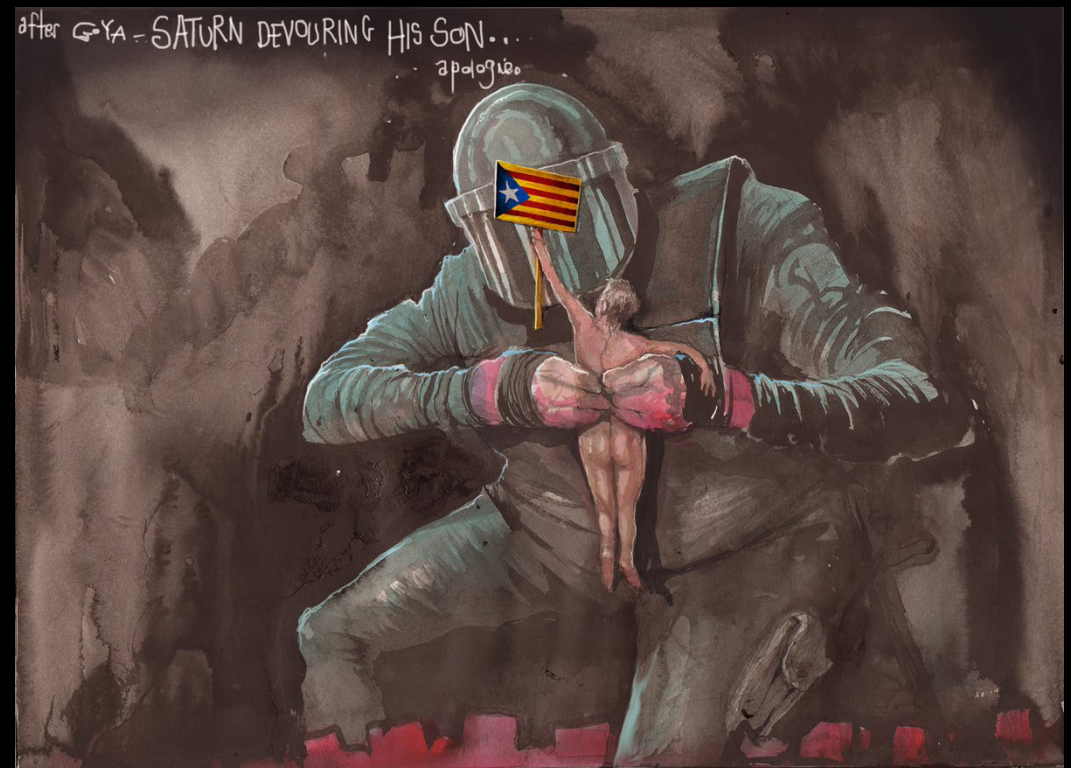

FIG 1

After Goya - Saturn Devouring His Son... (David Rowe, The Australian Financial Review, October 1st 2017)
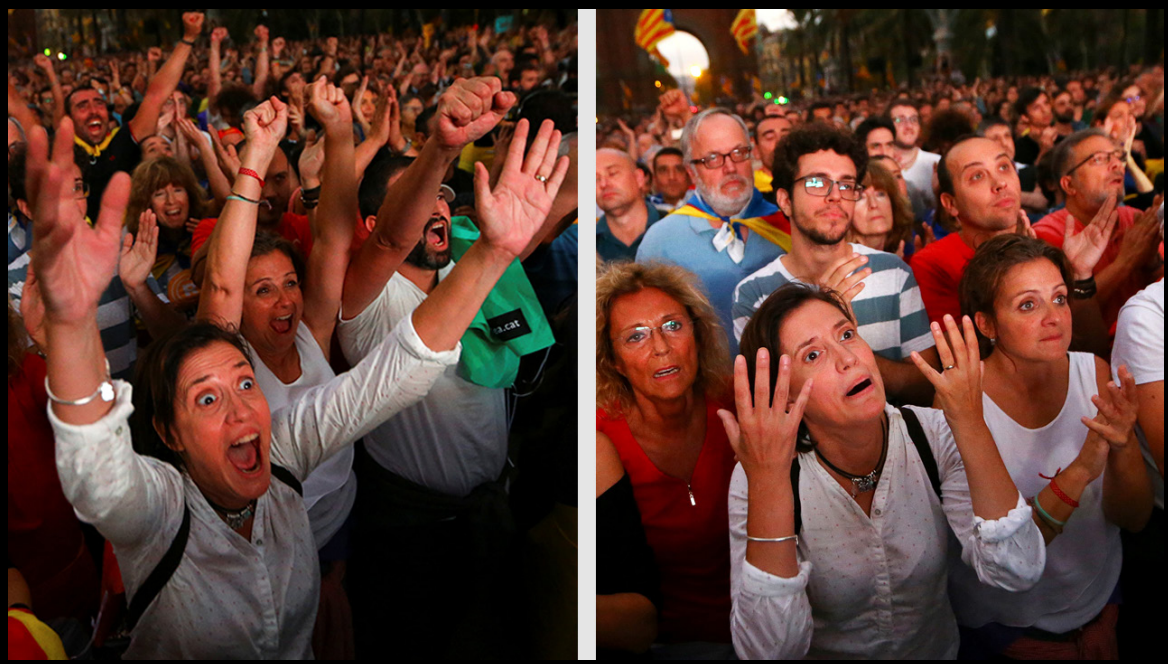

FIG 2

Joyful reactions to the declaration of independence and disappointment when it was placed on hold (Iván Alvarado, Reuters, October 10th 2017)

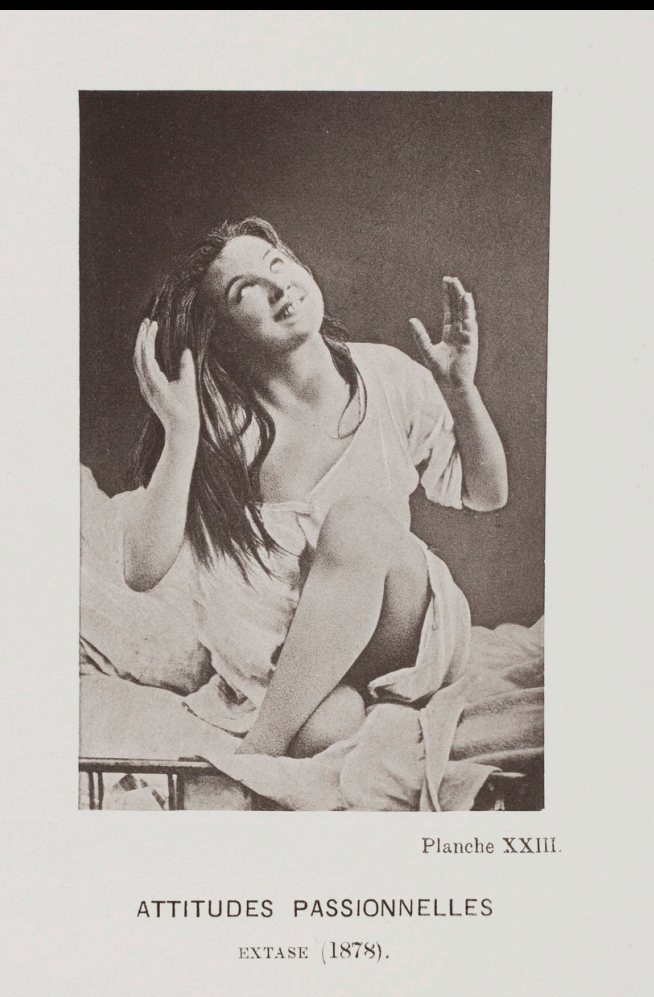

FIG 3

Iconographie

photographique de la

Salpêtrière, Plate 23:

Attitudes passionnelles:

Extase (Désiré-Magloire

Bourneville and Paul

Régnard, 1878) 
as media culture and it serves to articulate, reinforce, and question the political identities included in the procés (KELLNER, 2011).

\section{The diptych of the passions:} maenads and pathos in the referendum

On October 10th 2017, Carles

Puigdemont, president of the Generalitat de Catalunya (Catalan Government), unilaterally proclaimed, from within the parliament building, the independence of the Republic of Catalonia. The existence of this new state, which emerged after the October 1st referendum, lasted just 56 seconds, since the president himself took care to place the unilateral declaration of independence on hold, in order to call for a dialogue with the Spanish Government that would lead to the acknowledgement of the new Catalan republic ${ }^{6}$. While this brief declaration was taking place within the walls of the Palau del Parlament (Palace of the Catalan Parliament), thousands of expectant citizens had gathered on the street to see if the results of the referendum would lead to the proclamation of a new state. One of the images that had the greatest effect and exposure in the subsequent hours and days was taken by Iván Alvarado, a photographer from the agency Reuters, on the Passeig de Lluís Companys in Barcelona. Actually, it was two photographs, arranged one next to the other like a diptych (Fig. 2), which showed the change in mood of the independence supporters gathered in the street who were following the proceedings of the plenary session of parliament on giant screens ${ }^{7}$. The first photograph shows the joyful reaction of the people gathered there, while the other shows the disappointment at the declaration having been placed on hold. Both photographs were spread across the front pages of newspapers like $E l$ Mundo or $A B C$ in their October 11th editions, since they summarized the extremely differing emotions that were experienced during the 56 seconds in which the Republic of Catalonia existed. However, the gesturality contained in them also alludes to an expressive formula that has had a long history in the western visual tradition.

In the center of both images, a woman in a white shirt expressed and encapsulated on her face two emotions following the declaration of the republic: in the first one, with her arms raised at the moment of the proclamation, and in the second, with a grimace of pathos when she hears that it has been placed on hold. The female figure in this diptych of the passions has been left bound to the history of images thanks to the pathetic emotion contained in her face, since it evoked the figure of a maenad and revived an old pathos formula. The art historian Aby Warburg had become interested in what became called Pathosformel ever since his earliest research into the reliefs at the Parthenon, and he remained preoccupied with it until his last projects on the social memory of images (GOMBRICH, 1986: 177-185; DIDI-HUBERMAN, 2013: 172-201). The pathos formulae, propagated as visual formulas of the expression of pathetic emotions or suffering through gestural resources, were found in classic culture, mainly in statues like Laocoön, and in reliefs featuring maenads in a state of ecstasy. These pathos formulae were reused and reinterpreted later on, especially in 15th-century Florence, where a maenad from Antiquity could take the place of a Mary Magdalene, or a sculpture of a threatened Niobid could become a victorious David. In Warburg's view, this survival of Antiquity wasn't just the re-use of a visual formula, it referred to a more complex process that affected memory and gesturality. Warburg said:

"It is in the zone of orgiastic 
mass-seizures that we must look for the mint which stamps upon the memory the expressive movements of the extreme transports of emotion, as far as they can be translated into gesture language, with such intensity that these engrams of the experience of suffering passion survive as a heritage stored in the memory. They become the exemplars, determining the outline traced by the artist's hand as soon as maximal values of expressive movement desire to come to light in the artist's creative handiwork" (WARBURG in GOMBRICH, 1986: 245).

Warburg's ideas and the pathos formulae resonate surprisingly nowadays if we compare them with Alvarado's photograph, since the maenad in our passionate diptych expresses the maximum outer shudder in a mass event with a gesturality that is conserved in memory. The photo introduces into the context of the procés a pathos formulae that adds gestures and pathetic formulas which are furthermore anchored to a religious and warlike visual culture. The motif of the woman with her arms raised and gazing up at the sky ${ }^{8}$ evokes the old formulas of praying (BARASCH, 1999: 65-66), or iconographic expressions of hope (RIPA, 1996: 355) - the blessed soul with the beatified smile and mystical visionaries (STOICHITA, 1996: 151-181). Charcot's photographs of the hysterical Augustine also explore this ancient gesture (Fig. 3) which translates the passionate attitudes towards a formula in which arms and eyes are raised (DIDI-HUBERMAN, 2007). That same gesturality (with the added expressiveness of the face) can also be found in the classic maenads that were used to depict Mary Magdalene at the foot of the cross in paintings, reliefs and Florentine drawings of the 15th and 16th centuries, with raised arms and a disheveled face (WIND, 1937: 70-71). The polarity and versatility of the formula is evidenced with these examples, although other women with raised arms in war contexts could be added, such as the allegory of Europe in the painting The Consequences of War by Rubens (Fig. 4), the figure in Guernica by Picasso which reproduces this gesture, and the Mujer en un campo de batalla ("Woman on a battlefield") by Nicanor Vázquez Ubach, who guides the meaning towards lamentation. Along with this motif, expressed in the photograph on the left, pathos is shown intensely in the photo on the right.

The arms of the Catalan maenad have fallen slightly, her hands remain open but turned towards her and her face expresses the pain of a typical pathos formulae: as in Laocoön, her head is tilted and her mouth is half-open. In this case, she produces a gesture of dejection and defeat because of the holding of the proclamation of the new republic, like the one of the Niobids, whose tilted heads, lost expressions and half-open mouths express the pathos formulae through gesture codes that doctor Guillaume Duchenne de Boulogne tried to reproduce using electrical stimulation in the faces of his patients, and which were presented on boards as a kind of polyptych of the passions (Fig. 5).

These references that I have just mentioned are not intended to serve as a genealogy of images nor a visual dictionary that proves the existence of an iconographic continuity or a semiotic legibility between these images which appear, by chance or spontaneously, in Alvarado's photograph. I am quoting these references to make it clear that in the Pathosformel it is impossible to separate the shape from the content, as there is an imbrication between the emotional charge and the iconographic formula that is dragged in every time this gesturality is reused (CABELLO, 


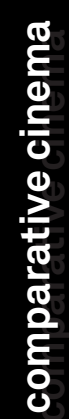

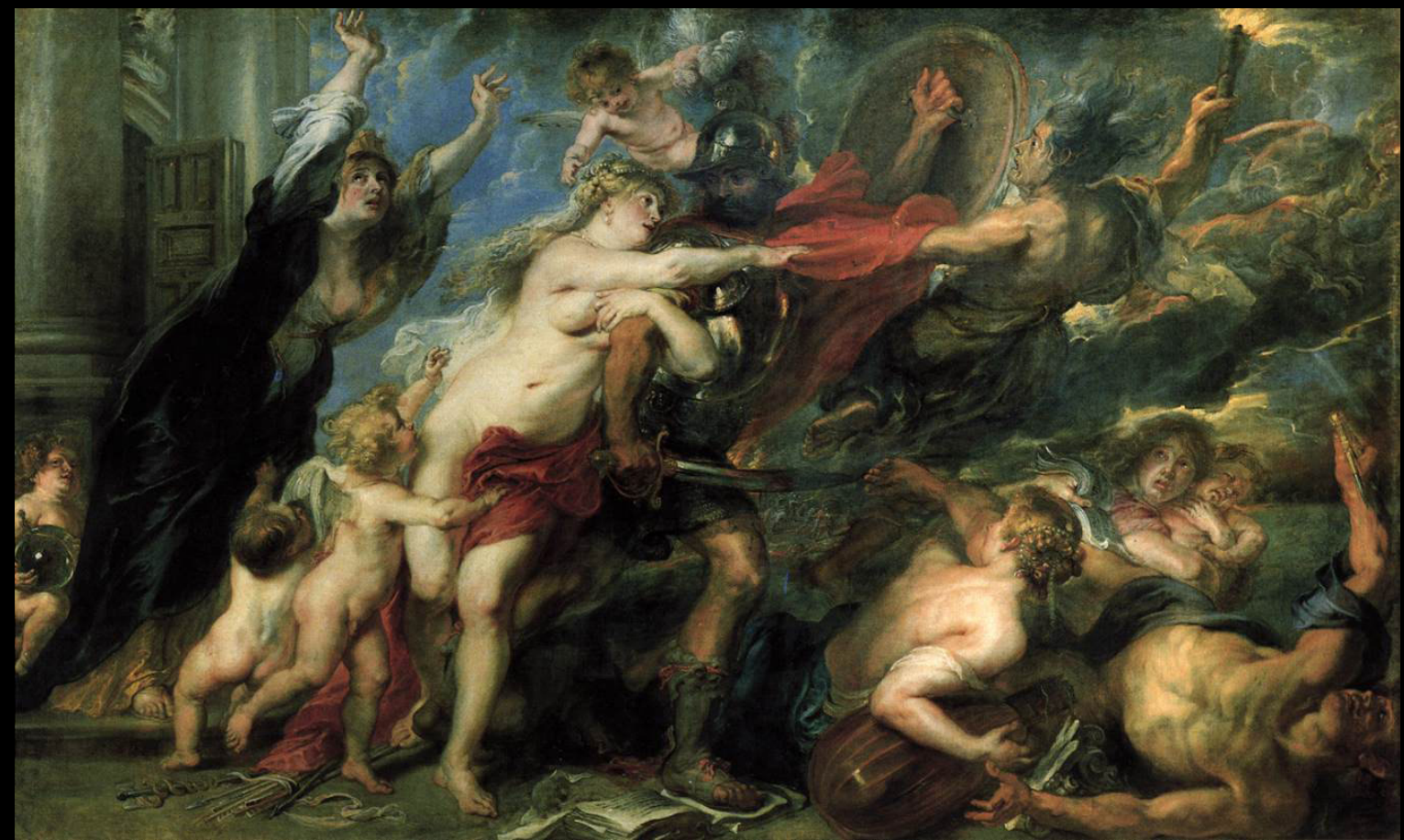

FIG 4

Consequences of War (Conseguenze della Guerra, Peter Paul Rubens, 1637-1638)

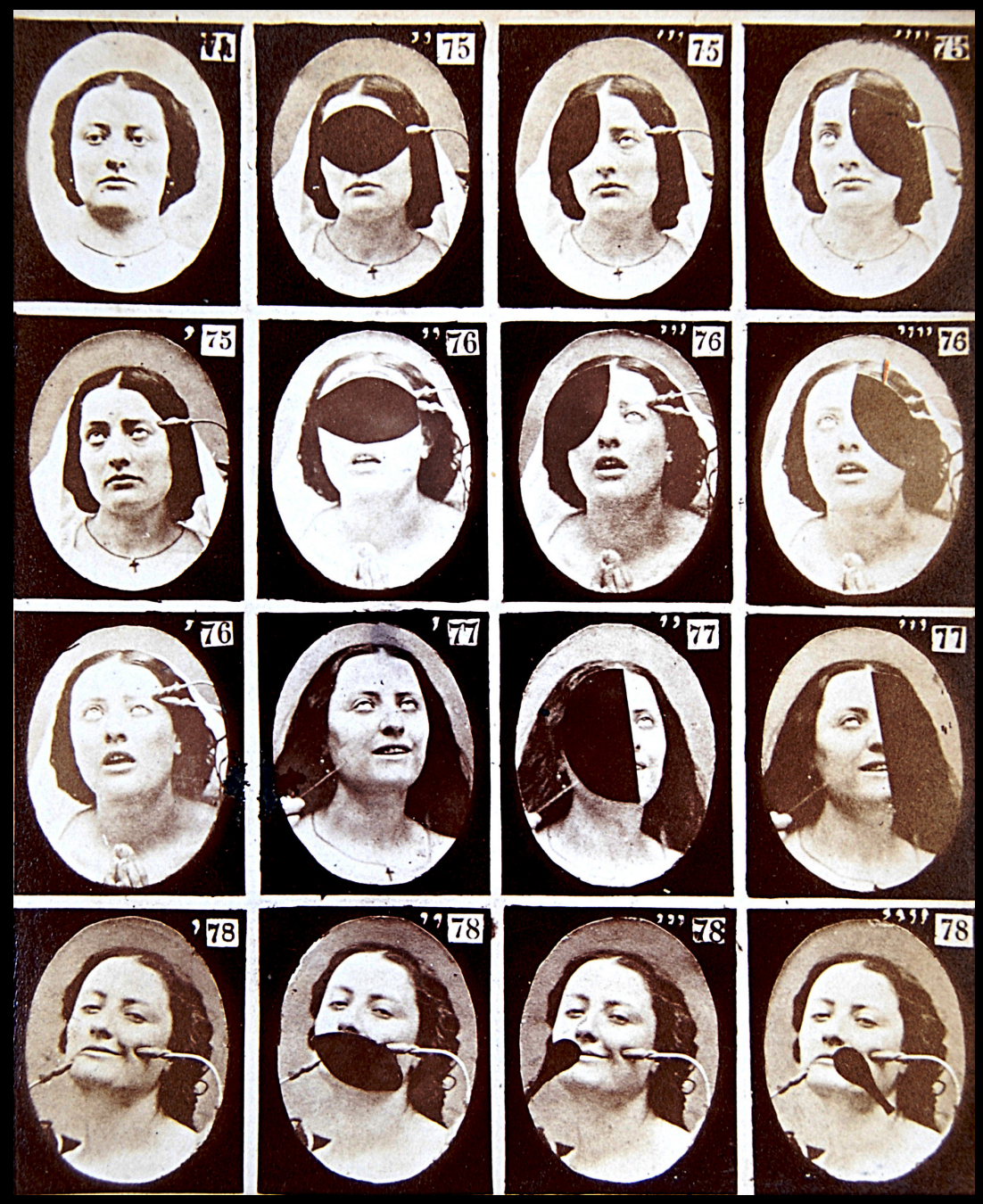

FIG 5

Le Mécanisme de la Physionomie Humaine, Plate 8 (Guillaume Duchenne de Boulogne, 1862)

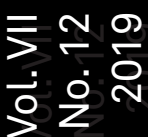


2017: 151-154; DIDI-HUBERMAN, 2013: 181). Jan Bialostocki also warned of this particularity with his concept of encompassing themes, which suggests that the reusing of a compositional formula implies that the elements of original meaning are dragged in, by a sort of iconographic law of gravity, towards a new image (BIALOSTOCKI, 1973: 111-124). This is where the importance of the gesture included in Alvarado's diptych lies, since the emotional charge and gesturality represented drag in the meanings highlighted in the aforementioned references. What defines the Pathosformel is that they are transiconographic formulas that go through time in a development that cannot be based on logical continuities or influence models. The Pathosformel, before they submit to the references of a historically-transmitted artistic culture of certain works to others or establish their legibility in semiotics (as if they were a hieroglyph that could be decoded), they pose an anthropological question regarding the temporal avatars of emotions mediated by images (CABELLO, 2017: 146-147; DIDIHUBERMAN, 2017:62).

Alvarado's diptych has the particularity of a Pathosformel that contains the mental and bodily dialectic of raising and falling: on one hand, the joy at the proclamation of the republic, and on the other, the disappointment at its suspension. Didi-Huberman has analyzed the gesture formulas that accompany and define political uprisings, and he has confirmed that Warburg disregarded the gesture formulas associated with insurrections in favor of his preference for pathos formulae associated with suffering (DIDI-HUBERMAN, 2017: 151-154). Alvarado's diptych includes both possibilities since they are images of a political movement that express the emotions of an uprising. The lifted arms in the left-hand photo convey hope and joy at the proclamation, while the grimace in the right-hand image expresses pain and disappointment at the defeat. This particularity causes Alvarado's diptych to function as an Eadweard Muybridge chronophotography in which we have two moments in the transformation of gesturality placed one beside the other. This placement shows the beginning and end of the emotional changes on a face that moves from joy to sadness, by way of cinematographic sequence. Bill Viola's video works on the expression of emotions operate within very similar parameters, because they feature faces which change their expression. For instance, in The Quintet of the Astonished, Viola confronts the spectator with the emotional expressions of a group of individuals inspired by a painting by Bosch, thereby establishing a dialogue between past and present by updating the rhetoric of affects in video art (DíAZ, 2008: 296-298). The video shows (in super-slow motion) the way in which the protagonists' features change when they show pain and emotion on their faces, a technique that Viola repeats in a lot of his works. Viola's videos are moving pictures that function as a visual treatise on the passions and a physiognomic compendium in which he explores the way in which gesture resources express emotions (Fig. 6).

Another noteworthy pathos gesture from the context of the procés is the one contained in a video distributed by Òmnium Cultural after the October 1 st referendum, and which showed the excessive force used by the police and the Guardia Civil (Civil Guard) on the day of the referendum. The video, titled Help Catalonia ${ }^{9}$, stars a woman who speaks to the camera with tears in her eyes (Fig. 7) and a choked-up voice, and who narrates the confrontations between the referendum voters and the police. The propaganda video is related to the visual tradition of people 
in tears who call for justice with glassy eyes (DIDI-HUBERMAN, 2017: 104). However, far from being emotionally natural, what is displayed is an excess of dramatized pathos (since she's an actress) and a gestural inflammation that is disconnected from real emotion. Warburg himself warned of the dangers of gestural rhetorical excesses, since they can override the meaning. An intense physiognomic expression like the one in the video can end up looking empty and sensationalist if the artist fails to make good use of the legacy that he has in his hands. Warburg pointed to these problems in the use that was made of certain gestural traditions during the Baroque period, and especially the simplification that the media of his time made of gesturality (GOMBRICH, 1986: 180-183 and 249-251), a warning that could well imply the contemporary use of these same gestures in the media context of the procés.

Both Alvarado's photographs and the protest video feature a woman as the protagonist of the Pathosformel. This fact doesn't seem fortuitous, given that it is the gender par excellence to corporeally channel the pathos process: in Eisenstein's films and in war photographs, women's figures tend to activate the gestural formula of pain and suffering (DIDI-HUBERMAN, 2017: 390). In the tradition of art history, women are also the main characters in pathos formulae, such as the maenads and Mary Magdalene.

Barack Obama's presidency represents a highly original example of the use of emotional formulas in political contexts. After his first election as president of the United States in 2008, Pete Souza, the official photographer at the White House, decided to open an account on the platform Flickr to show, on a global scale, the mandate of the new president ${ }^{10}$. From the thousands of photographs uploaded onto the platform we can find the use of emotional formulas or pathos formulae, especially in the images taken of the general public that attended Barack Obama's meetings or waited for him in the streets during his official trips. The images reproduce emotive formulas with raised arms and dramatic gestures ${ }^{11}$ that look more like a state of religious ecstasy (Fig.8) or to the reaction by a group of fans to the arrival of their idols (Fig. 9). The use of pathos is oriented towards the introduction of religious connotations into the public and political sphere, given that Obama is shown almost as a messiah or a sacred personage who causes emotive reactions in the people attending his events (VIVES-FERRÁNDIZ, 2012: 501516). The case of Barack Obama and social media is paradigmatic of the spectacle or celebritication of politics (OLIVA, PÉREZ-LATORRE, BESALÚ, 2015: a270), a phenomenon that is characteristic of the last decade in which elements of fame culture and celebrities have become inserted into politics. Fame culture explains why Obama is sometimes presented as someone who belongs more in Hollywood's star system, and whose presence incites the aforementioned reactions. In addition, the frequent presence of Hollywood actors in several of his official photographs such as Robert de Niro, Tom Hanks, George Clooney, Meryl Streep and Reese Witherspoon - does nothing but reinforce this celebritication (VIVESFERRÁNDIZ, 2014:185) ${ }^{12}$.

\section{Internet memes: gesturality, emotions and memory}

As I mentioned at the beginning, the images generated by the events of the procés are situated in a very characteristic media context: the web 2.0. A lot of these events have contained a counter-narrative, or 


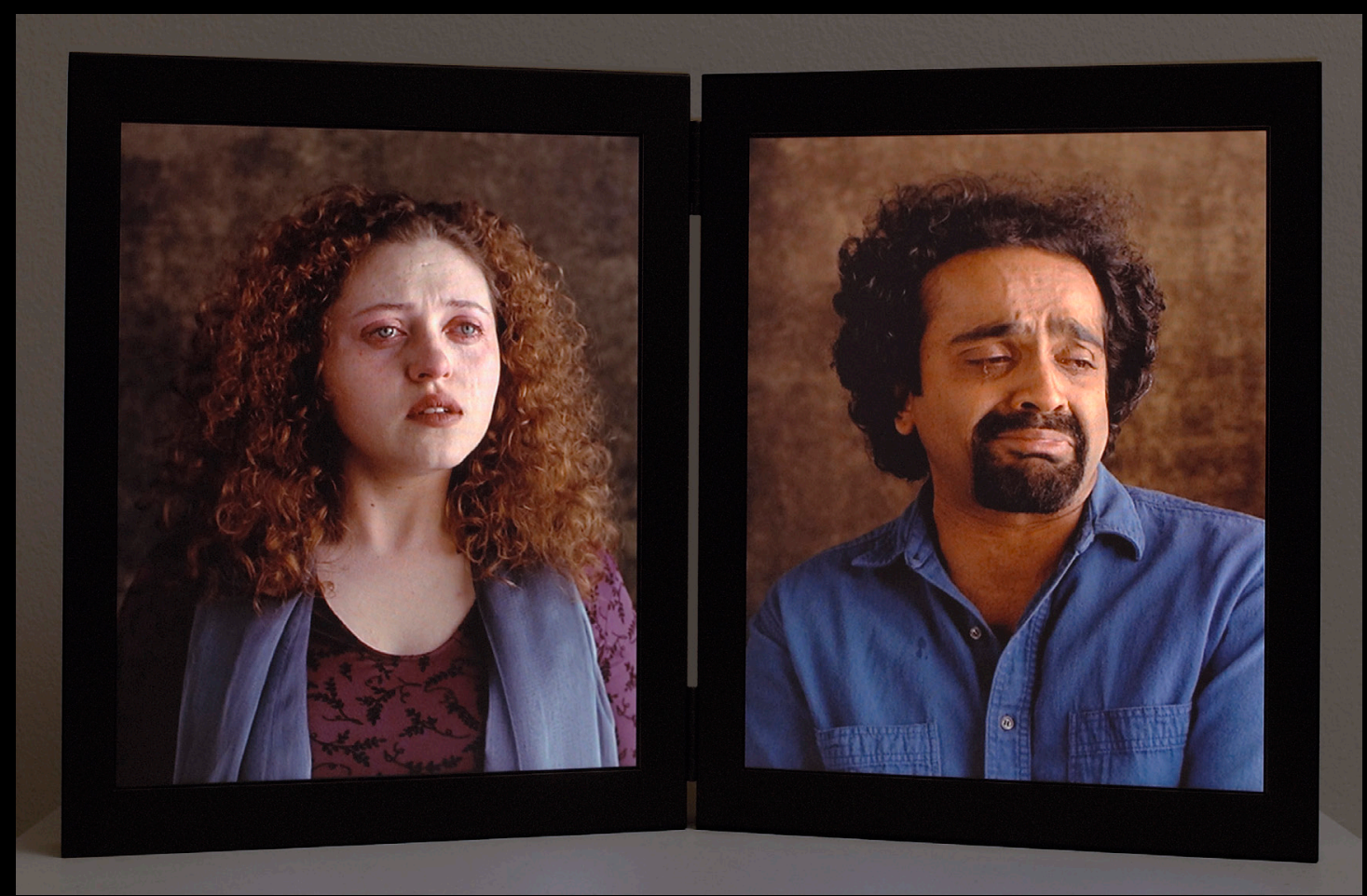

FIG 6

The Quintet of the Astonished (Bill Viola, 2000)

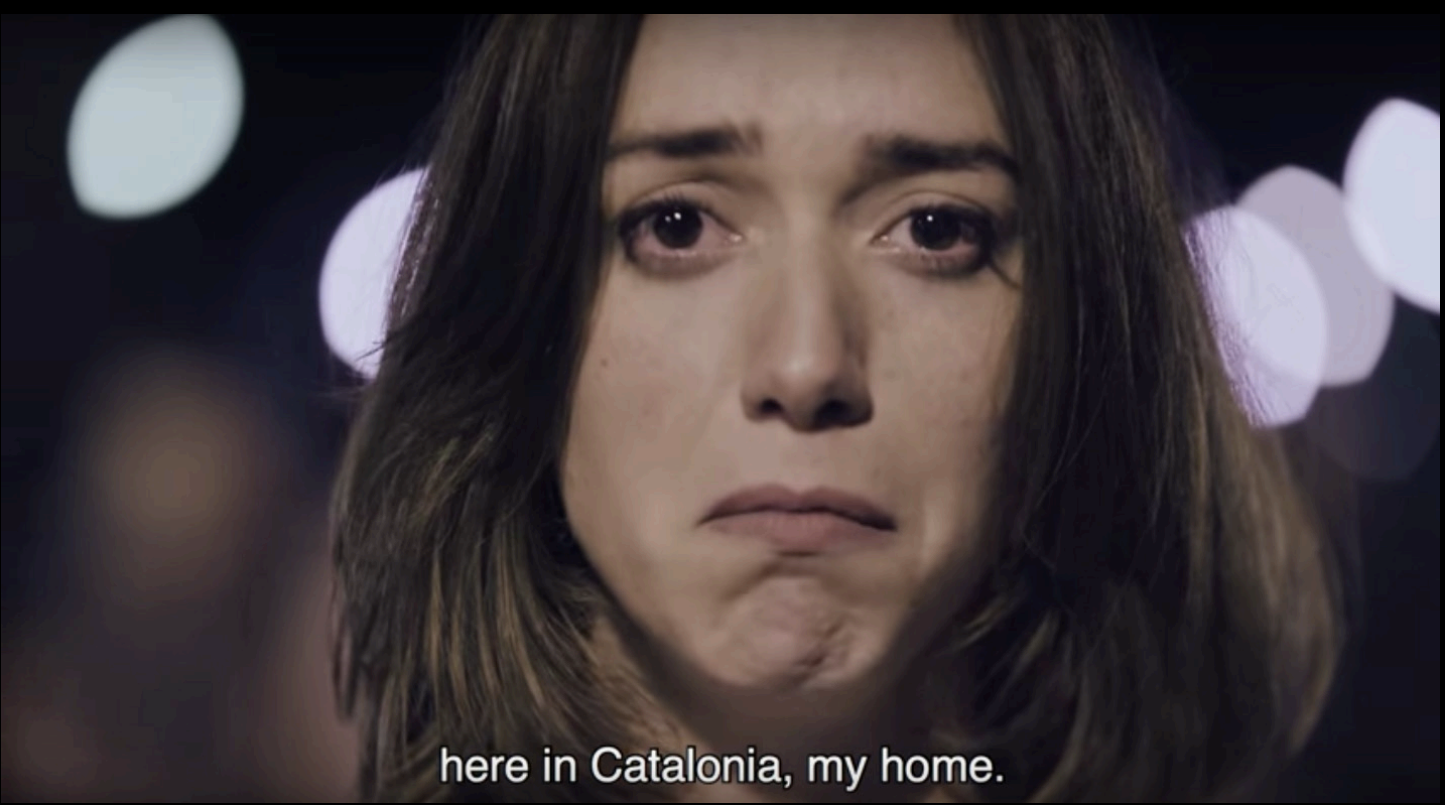

FIG 7

Help Catalonia (Òmnium Cultural, 2017) 
alternative story, driven by Internet memes in which users express their views on politics and identity through satirical images that can be circulated quickly and easily. In this case, both Alvarado's photography and the Help Catalonia video became the object of memes which took the gesturality and emotions depicted in them to create all kinds of humorous situations ${ }^{13}$. In these examples, we can see that gesturality is the basis for creating a successful meme, in the same way that gestures in the Pathosformel are what guarantee their reuse. In both cases, in the reactivation of pathos formulae and in memes, memory is a fundamental concept.

The term "meme" was coined by scientist Richard Dawkins in 1976 in his book The Selfish Gene. Dawkins spoke about memes as being analogous to genes. If the latter refer to the genetic material that is transmitted from one generation to another, then memes refer to cultural information that can be transmitted or replicated between generations. While genetics is focused on the study of genes, memetics analyzed the cultural material that is capable of being transmitted between generations:

"we need a name for the new replicator, a noun that conveys the idea of a unit of cultural transmission, or a unit of imitation. 'Mimeme' comes from a suitable Greek root, but I want a monosyllable that sounds a bit like 'gene'. I hope my classicist friends will forgive me if I abbreviate mimeme to meme" (DAWKINS, 2006: 192).

Dawkins' controversial idea claims that if genes are spread through sperm or eggs, then memes do it by "leaping from brain to brain via a process which [...] can be called imitation" (DAWKINS, 2006: 192). An Internet meme gets its name from Dawkins' vocabulary, since the way it spreads through the web is similar to the process of cultural transmission that the British biologist had studied. If a meme refers to the basic unit of cultural information that is transmitted and spread from generation to generation, the Internet meme owes its name to the image that is spread between users in a very similar way, reproducing and cloning itself between users, computers and smartphones.

Dawkins' ideas are very similar to a series of studies carried out by Ewald Hering and Richard Semon in the early 20th century which heavily influenced Aby Warburg's thinking. Warburg borrowed the terms "mneme" and "engram" from the two authors to refer, respectively, to the social symbolic memory and the expressive formulas used in representations of different times, the Pathosformel. The classic example of an engram is Warburg's study of Manet's painting, Déjeneur sur l'herbe, in which he points out how the French artist's painting draws from a Marcantonio Raimondi engraving that depicts The Judgment of Paris, which at the same time imitates a fragment by Raphael in the Vatican halls, all of them derived from classic sarcophagi. The engram alludes to the compositional pattern that has endured in the social "mneme" and which is reactivated in each period that it is reused. In other words, in the tradition of images, they persist in the social memory and can be downloaded, maintaining their original meaning or modifying it. The engram is a symbolized remnant of primitive corporeal reactions, and so the gesturality contained in it is fundamental to its continuity and its reactivation in time (GOMBRICH, 1986: 260-282; PINOTI, 2016: 417-431).

Internet memes function like Warburg's engrams, since their success lies in making use of an image's gesturality to maintain or empty it of 


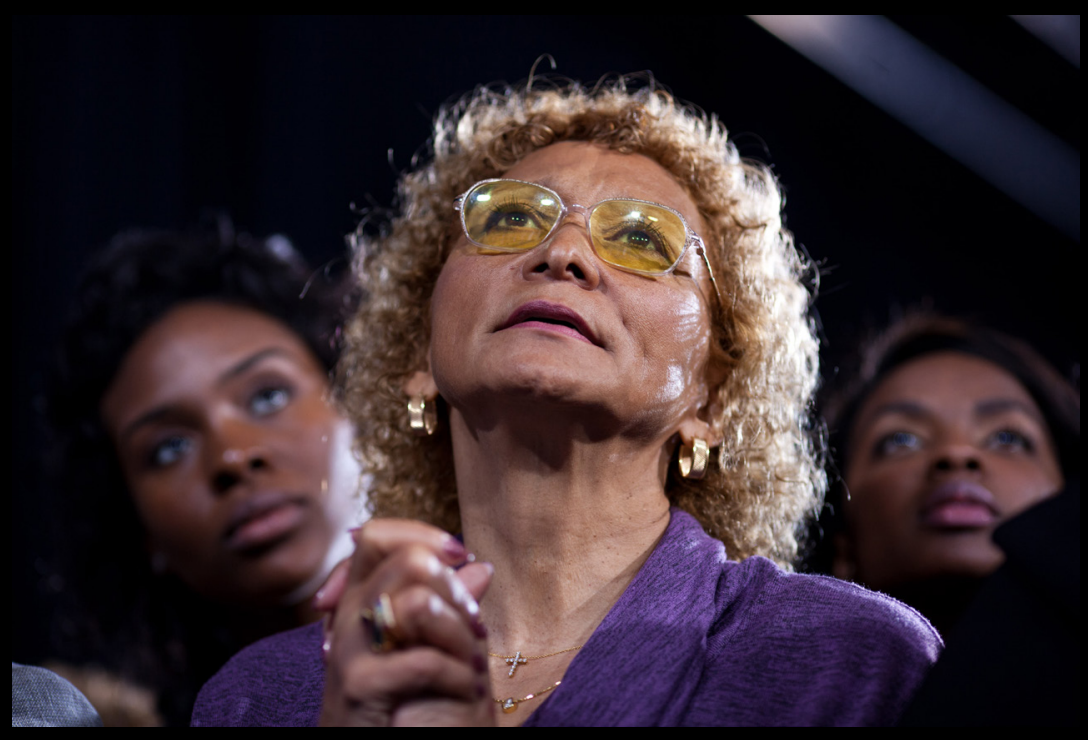

FIG 8

Audience members listen as President Barack Obama delivers remarks at a reception in Atlanta, Ga., March 16, 2012 (Official White House Photo by Pete Souza)

FIG 9

May 23, 2011

"I can still hear these Irish girls screaming, 'Barack! Barack! Michelle! Michelle!' It reminded me of the old black and white video footage of American girls screaming at the Beatles in concert. These girls were cheering as the President and First Lady took the stage at the College Green in Dublin." (Official White House Photo by Pete Souza)
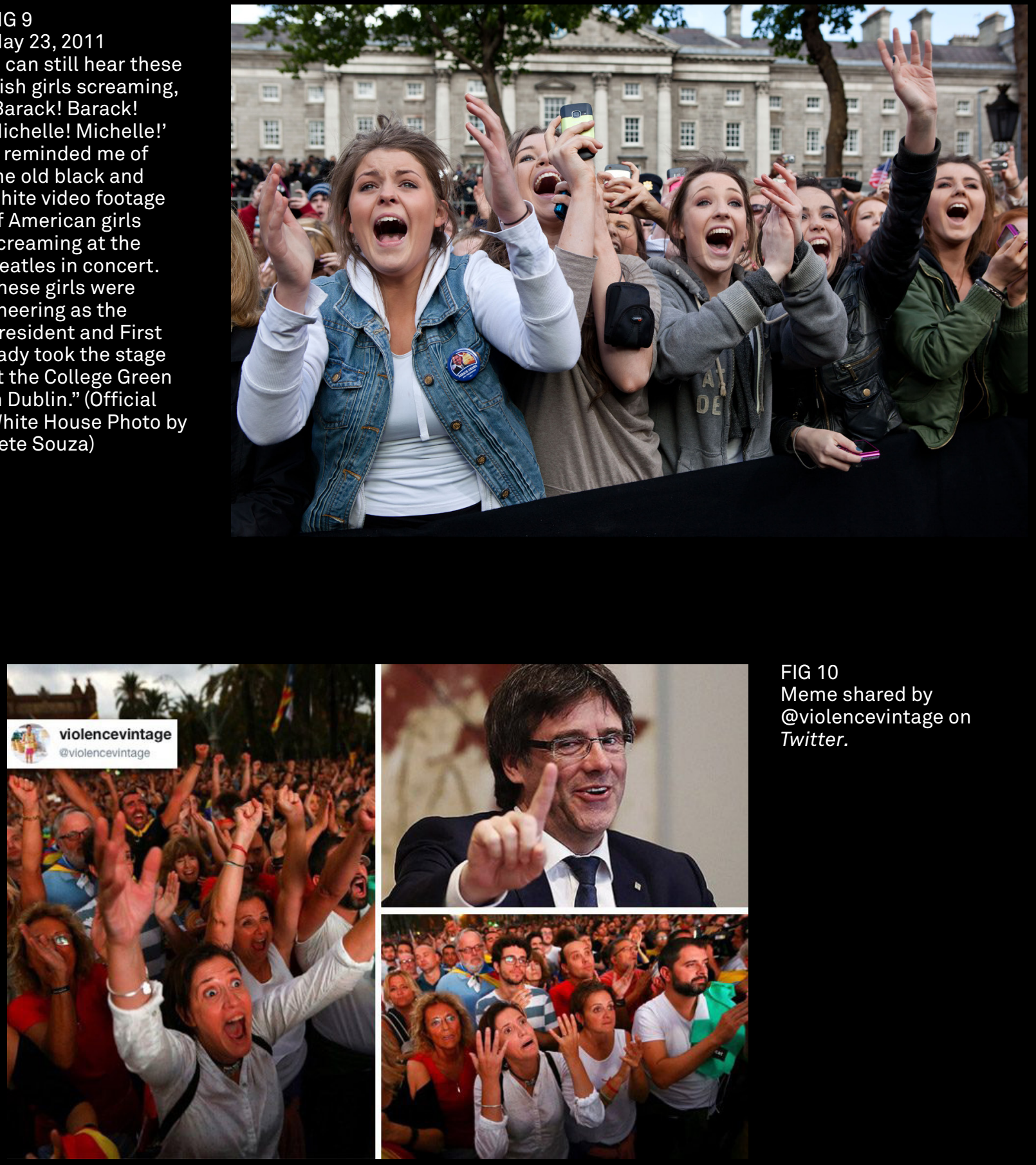

FIG 10

Meme shared by

@violencevintage on Twitter. 
its original meaning, and in this way, to give it new ones. As I have said already, a maenad's gesturality can be turned into a Christian figure or a Catalan protester. The gesturality contained in Alvarado's photos and the video can be transformed to create humorous or satirical content (Fig. 10). Nowadays, memes are the ideal materials for expressing emotions, and encapsulating expressions and meaning through gesturality (G. DE ANGELIS, 2016). Alvarado's photographic diptych and the video, when they express the gestural and emotive reactions of members of the public to the proclamation of independence, or the excess force used by the police, were the perfect materials for turning into a meme due to their hidden gestural potential. Also, the fact that they went viral does not only depend on their contained gesturality, but from a photographic point of view, they contained the key elements to make them into symbolic images and, therefore, memes: they are images that can represent the totality of an event, they were frequently repeated in the press and on television, and they are based on visual conventions that make it easier to symbolize and reuse them (BOUDANA, FROSH and COHEN, 2017).

The various uses that have been made of Alvarado's image, as well as any meme that we could provide in relation to the procés, all fall into what Hito Steyerl calls the "poor image" (STEYERL, 2014:33-48). This is a kind of image that is typical of the contemporaneity and possibilities of visual culture 2.0, characterized by its bad quality and its dynamic condition. It is an image in which its easy accessibility and its circulation and spread among the users that share it take precedence; it is an image that loses materiality nature but gains in speed. Poor images have created an economy of images of resistance the circulation of which between users seeks to provoke debate as if they were a pamphlet, a flysheet or a political leaflet, thereby turning the websites and platforms on which they are disseminated into battlefields on which to fight the war of images that I spoke of at the beginning of this piece. These poor images, in turn, hinge on the rationale of digital appropriability, a rationale that defines how users appropriate the images depicting an event and modify, alter, distort, and put them into circulation on these same platforms to express satirical (but also political) views of these events (GONDRA, G. DE ANGELIS, LÓPEZ DE MUNAIN and VIVES-FERRÁNDIZ, 2014: 111-135).

\section{By way of conclusion}

The analysis of Alvarado's photography and the Help Catalonia video, together with the memes that made use of the female faces featuring superlative pathos gestures, has enabled us to explore in greater depth the contemporary visual culture that has developed around the procés. On one hand, the point has been made that certain gestural resources and emotions have been reactivated in images of different political contexts (the procés and Obama's celebritication) and that our understanding of that emergence is based on asking ourselves what the temporal complexities of emotions mediated by images are. The possibility of giving meaning or legibility to the use of old visual formulas in a semiotic way is displaced by the paradigms of postmodernism which highlight the effects of presence that images from the past possess (MOXEY, 2014), and the search for alternative epistemological frameworks. On the other hand, Internet memes also operate using emotions mediated by images because they make use of the 
gestural potential of the images to reformulate them and provide them with new meanings so as to reinforce the views on politics and identity of the procés that are broadcast on the 2.0 webspace.

Translated by Daniela Torres Montenegro (See original texts at the end of the journal)

1/ The proposals can be consulted in Llibre blanc de la transició nacional de Catalunya: http://www.gencat.cat/eapc/revistes/RCDP/Documents_interes/RCDP_54/05_ 19Llibre_blanc_Sintesi.pdf [access: September 23rd 2018].

2/ https://www.theguardian.com/commentisfree/picture/2017/oct/27/martin-rowson-on-spain-catalonia-independence-power-struggle-cartoon [access: April 15th 2018].

3/https://twitter.com/Telegraph/status/914536533365051392/photo/1 [access: April 15th 2018].

4/ https://twitter.com/roweafr/status/914726155059646464/photo/1 [access: April 15th 2018].

5/ https://twitter.com/ferranmartin/status/914631167529426944 [access: April 15th 2018].

6/ https://www.ara.cat/2017/10/10/Declaracio_Independencia_amb_logo_-1.pdf [access: April 15th 2018].

7/ http://cadenaser.com/ser/2017/10/10/politica/1507663485_341695.html [access: April 15th 2018].

8/ The position of the photographer and the fact that the people attending the event were looking at giant screens set up on the street result in the fact that the image is taken with a sharp angle that emphasizes its symbolic meaning.

9/ https://www.youtube.com/watch?v=KLCoW_GiXAs [access: April 21st 2018].

10/ https://www.flickr.com/photos/obamawhitehouse/ [access: April 23rd 2018].

11/ https://www.flickr.com/photos/obamawhitehouse/8341815158/ https://www. flickr.com/photos/obamawhitehouse/6599542705/ https://www.flickr.com/photos/ obamawhitehouse/6599499635/ [access: April 23rd 2018].

$12 /$ The most crucial step in the spectacularization of Obama's image is his participation in a video that is shown on the official White House account on YouTube in which he confuses his role as president with that of the actor Daniel Day-Lewis. Director Steven Spielberg mentions that after the success of the movie Lincoln (2012) he decided to direct the film Obama, a project for which he had to decide who would play the role of the president. The fields of reality and fiction are confused since the actor chosen by the director to play the role is Daniel Day-Lewis, that is, the actor who had played Lincoln. The surprise erupts when the video shows Barack Obama himself playing Daniel Day-Lewis as Barack Obama. In the video, Obama (who is presented with the on-screen title as Daniel Day-Lewis) explains the process he used in order to portray President Obama, by working on his accent, gestures, motivations, etc., while the original soundtrack from the movie Lincoln plays in the background. The representation-within-the-representation reaches its high point when Obama, at the end of the video, maintains that he is in fact Daniel Day-Lewis. You can watch the video at the following link:

https://www.youtube.com/watch?v=ZyU213nhrh0\&list=TL09a694LmL_WsXIpJcGvkqoKEzL175UNj [access: April 23rd 2018]. 
13/ A compendium of these memes at: https://www.buzzfeed.com/guillermodelpalacio/video-help-catalonia?utm_term=.gqDmV2NyV\#.vcawGkZLG

http://www.publico.es/tremending/2017/10/11/twitter-los-mejores-me-

mes-de-la-casi-independencia-de-catalunya/

https://vozlibre.com/actualidad/la-independencia-los-8-segundos-las-mejores-reacciones-las-redes-5284/, https://verne.elpais.com/verne/2017/10/10/articulo/1507653719_231546.html [access: April 15th 2018].

\section{Bibliography}

BAL, Mieke (2016). Tiempos trastornados: análisis, historias y políticas de la mirada. Madrid: Akal.

BARASCH, Moshe (1999). Giotto y el lenguaje del gesto. Madrid: Akal.

BIALOSTOCKI, Jan (1973). Estilo e iconografía: contribución a una ciencia de las artes. Barcelona: Barral.

BOEHM, Gottfried (2011). ¿Más allá del lenguaje? Apuntes sobre la lógica de las imágenes. GARCÍA VARAS, Ana (ed.), Filosofía de la imagen (p. 87-106). Salamanca: Ediciones Universidad de Salamanca.

BOUDANA, Sandrine; FROSH, Paul and COHEN, Akiba A. (2017). Reviving icons to death: when historical photographs become digital memes. Media, culture and society, n. 39/8, p. 1-21.

CABELLO, Gabriel (2017). Entre historia del arte y práctica de las imágenes: aura y dolor de reminiscencias en Georges Didi-Huberman. Anthropos, 247, p. 146-163.

CANO BUESO, Juan (2017). Cataluña en su laberinto. Valencia: Tirant.

DAWKINS, Richard (2006). The sefish gene. Oxford and New York: Oxford University Press.

DÍAZ MARROQUÍN, Lucía (2008). La retórica de los afectos. Kassel: Reichenberger.

DIDI-HUBERMAN, Georges (2007). La invención de la histeria. Charcot y la iconografía fotográfica de La Salpêtrière. Madrid: Cátedra.

DIDI-HUBERMAN, Georges (2013). La imagen superviviente. Historia del arte y tiempo de los fantasmas según Aby Warburg. Madrid: Abada.

DIDI-HUBERMAN, Georges (2017). Pueblos en lágrimas, pueblos en armas. El ojo de la historia, 6. Santander: Shangrila.

DIDI-HUBERMAN, Georges (2017). Insurreccions. Barcelona: Museu Nacional d'Art de Catalunya.

FORTI, Steven; GONZÁLEZ I VILLALTA, Arnau; UCELAY-DA CAL, Enric (2017). ¿Qué es el procés? Sopesar los cambios en la política catalana entre 2006 y 2017. FORTI, Steven; GONZÁLEZ I VILLALTA, Arnau; UCELAY-DA CAL, Enric (eds.), El proceso separatista en Cataluña. Análisis de un pasado reciente (2006-2017) (p. 3-6). Granada: Editorial Comares.

GOMBRICH, Ernst (1986). Aby Warburg, An Intellectual Biography. Oxford: Phaidon.

GONDRA, Ander; G. DE ANGELIS, Marina; LÓPEZ DE MUNAIN, Gorka; VIVES-FERRÁNDIZ, Luis (2014). Cuando despertó, el elefante todavía estaba allí. La imagen del rey en la cultura visual 2.0. Barcelona: Sans Soleil Ediciones.

G. DE ANGELIS, Marina (2016). Del Atlas mnemosyne a GIPHY: La supervivencia de las imágenes en la era del GIF. e-imagen Revista 2.0, n. 3.

KELLNER, Douglas (2011). Cultura mediática. Estudios culturales, 
identidad y política entre lo moderno y lo posmoderno. Madrid: Akal.

MARTÍN PRADA, Juan (2012). Prácticas artísticas en internet en la época de las redes sociales. Madrid: Akal.

MITCHELL, W.J.T. (2013). Cloning terror. The war of images from 9/11 to present day. Chicago: The Chicago University Press.

MOXEY, Keith (2014). El tiempo de lo visual. La imagen en la historia. Barcelona: Sans Soleil.

OLIVA, Mercè; PÉREZ-LATORRE, Oliver; BESALÚ, Reinald (2015). Celebrificación del candidato. Cultura de la fama, marketing electoral y construcción de la imagen pública del político. Arbor. Ciencia, Pensamiento Y Cultura, 191(775), a270.

PINOTTI, Andrea (2016). La replica non indiferente. Mosse di iconología política all'epoca dell'internet-meme. GUASTINI, Daniele and ARDOVINO, Adriano (eds.), I percorsi dell'immaginazione. Studi in onore di Pietro Montani (p. 417-431). Cosenza: Luigi Pellegrini Editori.

RIPA, Cesare (1996). Iconología. Madrid: Akal.

SÁNCHEZ-CUENCA, Ignacio (2018). La confusión nacional. La democracia española ante la crisis catalana. Madrid: Los libros de la catarata.

STEYERL, Hito (2014). Los condenados de la pantalla. Buenos Aires: Caja Negra.

STOICHITA, Victor (1996). El ojo místico. Visión y pintura religiosa en el siglo de oro español. Madrid: Alianza.

VIVES-FERRÁNDIZ, Luis (2012). Yes we Flickr! Imágenes del poder en la era de la postfotografía. MíNGUEZ, Víctor (ed.), Las artes y la arquitectura del poder (p. 501-516). Castellón: Universitat Jaume I.

VIVES-FERRÁNDIZ, Luis (2014). La gran pantalla del mundo. La lógica barroca del capitalismo de ficción. Caracteres. Estudios culturales y críticos de la esfera digital, n. 3/1, p. 179-200.

WARBURG, Aby (2010). Atlas Mnemosyne. Madrid: Akal.

WIND, Edgar (1937). The Maenad under the cross. Comments on an observation by Reynolds. Journal of the Warburg Institute, n. 1, p. 70-71. 


\section{Luis Vives-Ferrándiz vol.VI1 comparative cinema

Sánchez

\section{Pathos en Cataluña: las políticas de las imágenes en la era de los memes}

El presente artículo se centra en el estudio de dos imágenes contextualizadas dentro del proceso de independencia de Cataluña con el fin de analizar el papel de la tradición visual en los escenarios políticos contemporáneos. La presencia de emociones y pathos en algunas imágenes icónicas relacionadas con el referéndum del 1 de octubre actualiza el legado intelectual de Aby Warburg y su noción de Pathosformel aplicada al estudio de la cultura visual contemporánea y a los memes de internet.

Palabras Clave

PATHOS

REFERÉNDUM

EMOCIONES

ABY WARBURG

CATALUÑA

MEME

Fecha de recepción: 01/05/2018

Fecha de aceptación: 10/10/2018

Luis Vives-Ferrándiz Sánchez Doctor en Historia del Arte por la Universitat de València, donde actualmente desarrolla su labor docente e investigadora. Sus principales líneas de investigación se centran en el estudio del tema de la vanitas en la esfera de la cultura barroca, así como sus extensiones al campo de la cultura visual contemporánea bajo la perspectiva del neobarroco. También ha realizado estudios sobre las reflexiones teóricas de la imagen y la cultura visual en la posmodernidad y el modo en que afectan a la práctica de la Historia del Arte. Sus últimas investigaciones han desarrollado el uso de la imagen fotográfica como elemento ideológico e identitario, el estudio de los nuevos regímenes escópicos y la iconoclasia contemporánea. 
Tanto el referéndum como los diLift me up and take me out of here Don't want to fight, don't want to die Just want to hear you cry. Arcade Fire, Intervention

\section{1 de octubre de 2017}

El denominado proceso constituyente en Cataluña, abreviado y conocido como procés, se refiere a la acción política encaminada a la consecución de la autodeterminación. Sus orígenes más inmediatos se encuentran en los deseos de mayor autogobierno por parte de Cataluña que quedaron expresados en el Estatuto de Autonomía del año 2006. Sin embargo, el Tribunal Constitucional declaró en el año 2010 una serie de artículos del mismo como inconstitucionales. Esta sentencia supuso la aceleración del proceso de autodeterminación pues se pasó de las reivindicaciones de autogobierno en el marco del estado español a la reclamación de un estado propio que colmase las históricas aspiraciones nacionales de Cataluña ${ }^{1}$. Uno de los acontecimientos más importantes del procés fue la celebración de un referéndum el 1 de octubre de 2017 que pretendía refrendar el camino hacia la independencia y que ha sido uno de los puntos más calientes de la crisis catalana al ser declarado ilegal por el estado español. En este contexto, los analistas hablan de un grupo independentista o soberanista que respalda los distintos actos, consultas y referéndums a favor de la independencia en la transición nacional de Cataluña (FORTI, GONZÁLEZ I VILLALTA, UCELAY-DA CAL, 2017: 3-6) frente al que se sitúan los sectores unionistas o constitucionalistas que defienden la permanencia de Cataluña en el estado español, el mantenimiento de las cotas de autogobierno y la aplicación de la legalidad constituyente (SÁNCHEZ-CUENCA, 2018; CANO BUESO, 2017). versos episodios que han conformado, y conforman, el procés han estado acompañados de imágenes oficiales o alternativas, periodísticas o amateurs, propagandísticas o contranarrativas que conforman la cultura visual del mismo. El propósito del presente artículo es estudiar dos imágenes vinculadas de manera directa con el referéndum del 1 de octubre que muestran una gestualidad y representan una emoción que actualizan las fórmulas de pathos que fueron definidas y estudiadas por Aby Warburg. El artículo, por lo tanto, pretende actualizar el sentido de estas fórmulas en un suceso político contemporáneo y entender la profundidad y complejidad de la cultura visual desarrollada en torno a las imágenes políticas del procés. Se trata, por un lado, de una fotografía del fotorreportero Iván Alvarado, de la agencia Reuters y publicada en la prensa, que muestra las reacciones de los asistentes a la breve proclamación de la república de Cataluña tras los resultados de la votación y, por otro lado, el vídeo Help Catalonia difundido por Òmnium Cultural en distintas plataformas para denunciar los excesos de la policía nacional a la hora de impedir la celebración del referéndum. Estas imágenes, además, fueron reformuladas y reconvertidas en memes que circularon por la red con la intención de generar nuevos sentidos a partir de la gestualidad contenida en las mismas. El artículo también estudia la relación entre los memes de internet, la gestualidad y la problemática de las fórmulas de pathos a partir del concepto de memoria.

\section{Iconomaquia 2.0}

Muchos de los conflictos políticos contemporáneos se viven y desarrollan como una guerra de imágenes (MITCHELL, 2013) en la que la difusión y control (incluso la censura) de las mismas es fundamental para la trans- 
misión de ideas, valores y conceptos. La expresión "guerra de imágenes» es puramente metafórica y describe el heterogéneo y amplio repertorio de imágenes que son convocadas desde la historia del arte o desde distintas tradiciones visuales para expresar y confrontar las visiones políticas de cualquier conflicto. En el caso del procés, hay que recalcar que determinadas e icónicas imágenes de guerra han sido un recurso del que se ha echado mano desde los medios de comunicación para contar lo que aconteció en Cataluña el día del referéndum. Por ejemplo, el caricaturista del periódico The Guardian, Martin Rowson, entendió que el procés podría derivar en una contienda bélica real y publicó una caricatura inspirada en Premonición de la Guerra Civil de Salvador Dalí en la que Rajoy y Puigdemont son los combativos protagonistas de la imagen². Por otra parte, el caricaturista Blower, del diario The Telegraph, se sirvió de la famosa fotografía de Gerda Taro y Robert Capa de la Muerte de un miliciano para ilustrar el exceso de fuerza de la policía en la jornada electoral del 1 de octubre al disponer a Federico Borrell frente a una patrulla antidisturbios ${ }^{3}$. El dibujante del Financial Review de Australia, David Rowe, optó por adaptar el Saturno devorando a sus hijos de Goya (Fig. 1) pero sustituyendo al dios por un policía nacional de gran tamaño que trata de devorar a una mujer que porta una bandera independentista catalana ${ }^{4}$. Goya también sirvió de inspiración para Ferran Martín, de El Jueves, que se sirvió de Duelo a garrotazos para contar la violencia vivida el día del referéndum del 1 de octubre cambiando los villanos por un policía armado con porra y un ciudadano que alza una urna para votar ${ }^{5}$.

Estos ejemplos están asentados en la historia visual, cultural e identitaria de España y son convocados por los dibujantes porque se trata de ejemplos icónicos y fácilmente reconocibles y porque actúan como marcos retóricos que se adaptan para contar un suceso contemporáneo. Su reutilización evidencia que las imágenes, a raíz del giro visual de la posmodernidad, sean del tipo que sean (artísticas, documentales, periodísticas...), desempeñan un papel epistemológico asentado en su capacidad para ser agentes conformadores de sentido en función de una lógica icónica propia (BOEHM, 2011: 87-106). En estos ejemplos mencionados, además, el pasado se emplea para dar sentido al presente en un ejercicio de historia que busca construir una relación entre ambos tiempos. Las imágenes del pasado actúan como interlocutoras de nuestros problemas (BAL, 2016). Así, las obras de Goya, Capa o Dalí son convocadas como los muñecos de un ventrílocuo para hacerlas hablar ante un suceso contemporáneo en función del potencial epistemológico que poseen las imágenes.

Asimismo, el procés se desarrolla en un escenario mediático complejo en el que imágenes de la prensa, los medios de comunicación o la propaganda oficial comparten espacio con el heterogéneo conglomerado de imágenes que se crean, comparten y difunden en plataformas como Facebook, Twitter, YouTube, Instagram o WhatsApp y que definen la llamada web 2.0. La principal característica de la web 2.0 es que los usuarios de estas plataformas tienen la capacidad de generar contenidos que se difunden y popularizan hasta hacerse virales (MARTíN, 2012). Con la web 2.0, los usuarios pueden crear imágenes cómicas, satíricas o de denuncia relacionadas con el procés y difundirlas en forma de memes o bien distribuir aquellos que se han puesto en circulación. La web 2.0 es, por lo tanto, un (metafórico) campo de batalla fundamental pues sirve para expresar y transmitir las distintas visiones políticas que están en juego en la crisis catalana. Este conjunto de imágenes, que es tremendamente heterogéneo al 
mismo tiempo que difícil de controlar y estudiar debido a su amplitud y breve existencia, conforma la llamada cultura mediática y sirve para articular, reforzar o cuestionar identidades políticas incardinadas en el procés (KELLNER, 2011).

\section{El díptico de las pasiones: ménades y pathos en el referéndum}

El 10 de octubre de 2017, el presidente de la Generalitat de Cataluña Carles Puigdemont proclamaba en el pleno del parlamento la independencia de la república de Cataluña de manera unilateral. El nuevo estado, surgido tras el referéndum del 1 de octubre, apenas tuvo una existencia de 56 segundos pues el mismo presidente se encargó de dejar en suspenso la declaración unilateral de independencia para solicitar un diálogo con el estado español que condujese al reconocimiento de la nueva república catalana ${ }^{6}$. Al mismo tiempo que esta breve declaración se efectuaba entre las paredes del Palau del Parlament, en la calle se habían concentrado miles de ciudadanos expectantes por ver si los resultados del referéndum desembocaban en la proclamación de un nuevo estado. Una de las imágenes que más repercusión y difusión tuvo en las horas y días posteriores fue tomada por Iván Alvarado, fotógrafo de la agencia Reuters, en el Paseo Lluís Companys de Barcelona. En realidad, se trata de dos fotografías, difundidas una al lado de la otra a modo de un díptico (Fig. 2), que reflejan el cambio en el estado de ánimo de los independentistas reunidos en la calle que seguían el desarrollo del pleno del parlamento por medio de pantallas gigantes ${ }^{7}$. En la primera de las instantáneas se muestra la reacción de júbilo de los congregados ante la proclamación de la república mientras que la otra recoge la decepción por el suspenso en que quedaba la declaración. Ambas fotografías se difundieron en las portadas de periódicos como El Mundo o $A B C$ en sus ediciones del 11 de octubre de 2017 ya que condensaban las emociones tan dispares vividas en los 56 segundos de existencia de la república de Cataluña. No obstante, la gestualidad contenida en las fotografías también aludía a una fórmula expresiva de largo recorrido en la tradición visual occidental.

En el centro de las dos imágenes, una mujer con camisa blanca expresaba y condensaba en su rostro las dos emociones ante el anuncio de la república: por un lado, con los brazos levantados en el momento de la proclamación y, por otro, con una mueca de pathos al escuchar que ésta quedaba en suspenso. La figura femenina de este díptico de las pasiones quedaba anudada en la historia de las imágenes gracias a la emoción patética contenida en su rostro ya que, con ella, evocaba la figura de una ménade y reanimaba una antigua fórmula de pathos. El historiador del arte Aby Warburg se interesó por las llamadas Pathosformel desde sus primeras investigaciones sobre los relieves del Partenón y le preocuparon hasta sus últimos proyectos sobre la memoria social de las imágenes (GOMBRICH, 1992: 168-175; DIDI-HUBERMAN, 2013: 172-201). Las fórmulas de pathos, entendidas como fórmulas visuales de expresión de emociones patéticas o de sufrimiento a partir de los recursos gestuales, se encontraban en la cultura clásica, principalmente en estatuas como el Laocoonte o en relieves con ménades en éxtasis. Esas fórmulas de pathos fueron reutilizadas 0 reinterpretadas en momentos posteriores, sobre todo en la Florencia del siglo $X V$, donde una ménade de la Antigüedad podía pasar por una María Magdalena o la escultura de un Nióbida amenazado podía reconvertirse en un David victorioso. Para Warburg, esta supervivencia de la Antigüedad no respondía a una simple reutilización de una fórmula visual sino que hacía referencia a un 
proceso más complejo que afectaba

a la memoria y a la gestualidad. Decía Warburg que

«en la región orgiástica de masas hay que buscar el carácter acuñado que introduce en la memoria las formas de expresar el estremecimiento interior máximo, en la medida en que éste puede expresarse en un lenguaje de gestos, con tal fuerza que tales engramas de experiencia pasional sobreviven como patrimonio conservado en la memoria y determinan [...] los valores máximos del lenguaje gestual» (WARBURG, 2010:3).

Las ideas de Warburg y las fórmulas de pathos resuenan con sorprendente actualidad si se confrontan con la fotografía de Alvarado pues la ménade de nuestro díptico pasional expresa el estremecimiento exterior máximo en un acto de masas con una gestualidad conservada en la memoria. La fotografía de Alvarado introduce en el contexto del procés una fórmula de pathos que incorpora gestos y fórmulas patéticas que están ancladas, además, en una cultura visual religiosa y bélica. El motivo de la mujer con los brazos levantados y la mirada hacia el cielo ${ }^{8}$ remite a las viejas fórmulas de la oración (BARASCH, 1999: 65-66) o los tipos iconográficos de la esperanza (RIPA, 1996: 355), el alma bienaventurada con la sonrisa beatífica y las visionarias místicas (STOICHITA, 1996: 151-181). Las fotografías de Charcot de la histérica Augustine también exploran este gesto antiguo (Fig. 3) que traduce las actitudes pasionales hacia una fórmula en la que brazos y ojos se elevan (DIDI-HUBERMAN, 2007). La misma gestualidad, con el añadido expresivo del rostro, es la que se puede encontrar en las ménades clásicas que sirvieron para figurar a María Magdalena al pie de la cruz en pinturas, relieves y dibujos florentinos de los siglos XV y XVI, con los brazos levantados y el rostro desencajado (WIND, 1937: 70-71). La polaridad y versatilidad de la fórmula queda evidenciada con estos ejemplos aunque se podrían añadir otras mujeres con brazos en alto en contextos bélicos como la alegoría de Europa del cuadro de Los desastres de la guerra de Rubens (Fig. 4), la figura del Guernica de Picasso que reproduce este gesto o la Mujer en un campo de batalla de Nicanor Vázquez Ubach, que orientan el significado hacia el lamento. Junto a este motivo, figurado en la fotografía de la izquierda, el pathos se muestra de manera intensa en la fotografía de la derecha. Los brazos de la ménade catalana han caído ligeramente, las manos se mantienen abiertas pero giradas hacia ella y el rostro expresa el dolor con una típica fórmula de pathos: como en el Laocoonte, la cabeza se ladea y la boca queda entreabierta. En este caso, es un gesto de abatimiento y de derrota por la suspensión de la proclamación del nuevo estado, como el de los Nióbidas, cuyos rostros ladeados, mirada perdida y boca entreabierta expresan la fórmula de pathos por medio de unos códigos gestuales que el médico Guillaume Duchenne de Boulogne trató de reproducir con estimulaciones eléctricas en los rostros de sus pacientes y que presentó en tablas a modo de polípticos de las pasiones (Fig. 5).

Estas referencias que se acaban de mencionar no pretenden ser una genealogía de imágenes ni un diccionario visual que demuestren una continuidad iconográfica o legibilidad semiótica entre estos gestos que aparecen, de forma casual o espontánea, en la fotografía de Alvarado. Estas referencias son convocadas para evidenciar que en las Pathosformel es imposible separar la forma del contenido pues hay una imbricación entre carga emotiva y fórmula iconográfica que se arrastra con cada reutilización de dicha gestualidad (CABELLO, 2017: 151-154; DIDI-HUBERMAN, 2013: 181). Esa particula- 
ridad también fue advertida por Jan Bialostocki con su concepto de tema de encuadre, que apunta a que la reutilización de una fórmula compositiva implica que elementos del significado original se arrastren, por una suerte de ley de la gravedad iconográfica, hacia la nueva imagen (BIALOSTOCKI, 1973: 111124). Ahí radica la importancia del gesto contenido en el díptico de Alvarado pues la carga emotiva y la gestualidad representada arrastran los significados apuntados en las referencias mencionadas. Lo que define a las Pathosformel es que son fórmulas transiconográficas que atraviesan el tiempo en un devenir que no puede basarse en continuidades lógicas o en modelos de influencia. Las Pathosformel, antes que someterse a las referencias de una cultura artística históricamente transmitida de unas obras a otras o fundar su legibilidad en la semiótica (como si fuese un jeroglífico que se pueda descifrar), plantean una pregunta antropológica acerca de los avatares temporales de las emociones mediatizas por imágenes (CABELLO, 2017: 146-147; DIDI-HUBERMAN, 2017: 62).

El díptico de Alvarado tiene la particularidad de mostrar una Pathosformel que contiene la dialéctica, psíquica y corporal, del levantamiento y del abatimiento: por un lado, la alegría por la proclamación de la república y, por otro, la decepción por la suspensión. Didi-Huberman ha analizado las fórmulas gestuales que acompañan y definen los levantamientos políticos y ha constatado que Warburg desatendió las fórmulas gestuales asociadas con las insurrecciones frente a sus preferencias por las fórmulas de pathos asociadas al sufrimiento (DIDI-HUBERMAN, 2017: 151-154). El díptico de Alvarado encierra ambas posibilidades ya que se trata de imágenes de un movimiento político que expresan las emociones de un levantamiento. Los brazos en alto de la fotografía de la izquierda aluden a la esperanza y alegría por la proclamación mientras que la mueca de la imagen de la derecha expresa dolor y decepción por la derrota. Esta particularidad hace que el díptico de Alvarado funcione como una cronofotografía de Eadweard Muybridge en la que vemos dos instantes de un devenir gestual dispuestos uno junto al otro. Con esta disposición se muestran el principio y el final del cambio emotivo de un rostro que transita de la alegría a la tristeza, a modo de secuencia cinematográfica. Los trabajos con el vídeo de Bill Viola sobre la expresión de las emociones se mueven en unos parámetros muy similares pues en ellos se representan rostros que cambian de expresión. Por ejemplo, en The Quintet of the Astonished Viola confronta al espectador con las expresiones de las emociones de un grupo de individuos inspirado en un cuadro de El Bosco planteando un diálogo entre el pasado y el presente al actualizar la retórica de los afectos en el videoarte (DÍAZ, 2008: 296-298). El vídeo muestra a cámara súper lenta cómo cambian las facciones de los protagonistas al representar el dolor y la emoción en sus rostros, recurso que Viola repite en muchos de sus trabajos. Los vídeos de Viola son cuadros en movimiento que funcionan como un tratado visual de las pasiones y un compendio fisionómico en el que se exploran los recursos gestuales para expresar emociones (Fig. 6).

Otro gesto de pathos a destacar del contexto del procés es el que se encuentra en un vídeo difundido por Òmnium Cultural tras el referéndum del 1 de octubre en el que mostraba las actuaciones desmedidas de la policía y la guardia civil el día de las votaciones. El vídeo, titulado Help Catalonia ${ }^{9}$, está protagonizado por una mujer que se dirige a cámara con ojos llorosos (Fig. 7) y voz entrecortada para narrar los enfrentamientos entre los votantes del referéndum y la policía. El vídeo propagandístico entronca con la tradición visual de pueblos en lágrimas 
que reclaman justicia con sus ojos vidriosos (DIDI-HUBERMAN, 2017: 104). Sin embargo, lejos de ser una emoción natural, lo que se despliega es un exceso de pathos teatralizado (pues es una actriz) y una inflación gestual que está desconectada de la emoción real. El propio Warburg ya advirtió de los peligros de los excesos retóricos de los gestos pues conseguían desactivar su sentido. Una expresión fisionómica intensa como la del vídeo puede resultar hueca y sensacionalista si el artista no sabe hacer un uso adecuado del legado que cae en sus manos. Warburg señaló estos problemas en el uso que durante el Barroco se hizo de algunas tradiciones gestuales y, especialmente, con la simplificación que los medios de comunicación de su tiempo hacían con los gestos (GOMBRICH, 1992: 171174 y 234-235), advertencia que bien se puede aplicar al uso contemporáneo de esos mismos gestos en el contexto mediático del procés.

Tanto las fotografías de Alvarado como el vídeo de denuncia cuentan con una mujer como protagonista de la Pathosformel. Este hecho no parece fortuito pues es el género por excelencia para conducir corporalmente el proceso de pathos: en las películas de Eisenstein o en las fotografías de guerra son cuerpos de mujeres los que suelen activar la fórmula gestual del dolor y el sufrimiento (DIDI-HUBERMAN, 2017: 390). En la tradición de la historia del arte también son mujeres las que protagonizan las fórmulas de pathos como las ménades o la figura de María Magdalena.

El recurso a fórmulas emotivas en contextos políticos tiene un capítulo muy original en el caso de la presidencia de Barack Obama. Tras su primera elección como presidente de los Estados Unidos en el año 2008, el fotógrafo oficial de la Casa Blanca, Pete Souza, decidió abrir una cuenta en la plataforma Flickr para mostrar a escala global el mandato del nuevo presidente ${ }^{10}$. De entre las miles de fotografías que se subieron a la plataforma es posible encontrar el recurso a las fórmulas emotivas o de pathos, sobre todo en las imágenes tomadas del público que asistía a los mítines de Barack Obama o le esperaba en las calles durante sus viajes oficiales. Las imágenes reproducen unas fórmulas emotivas con los brazos en alto o con gestos dramáticos ${ }^{11}$ más parecidos a un éxtasis religioso (Fig. 8) o a la reacción de un grupo de fans ante la llegada de sus ídolos (Fig. 9). El recurso a las fórmulas de pathos se orienta hacia la introducción en la esfera pública y política de connotaciones religiosas pues Obama se muestra casi como un mesías o un personaje sagrado que provoca reacciones emotivas entre los asistentes (VIVES-FERRÁNDIZ, 2012: 501-516). El caso de Barack Obama y las redes sociales es paradigmático de la espectacularización o celebrificación de la política (OLIVA, PÉREZ-LATORRE, BESALÚ, 2015: a270), un fenómeno característico de la última década, en la que elementos de la cultura de la fama y las celebridades se han introducido en la política. La cultura de la fama explica que Obama sea presentado en ocasiones como alguien más propio del star system de Hollywood cuya presencia provoca las reacciones comentadas. Además, la presencia recurrente de actores de Hollywood en varias de las fotografías oficiales, como Robert de Niro, Tom Hanks, George Clooney, Meryl Streep o Reese Witherspoon, no hace sino reforzar esta celebrificación (VIVES-FERRÁNDIZ, 2014: 185) ${ }^{12}$.

\section{Memes de internet: gestualidad, emociones, memoria}

Como se ha comentado al comienzo, las imágenes generadas alrededor de los acontecimientos del procés se sitúan en un contexto mediático muy característico: la web 2.0. Muchos de 
esos acontecimientos han contado con una contranarrativa, o relato alternativo, protagonizado por los memes de internet en los que los usuarios expresaban sus visiones políticas e identitarias por medio de unas imágenes satíricas de rápida y fácil circulación. En el caso que nos ocupa, tanto la fotografía de Alvarado como el vídeo Help Catalonia fueron objeto de memes que tomaron los gestos y las emociones que en ellos estaban representadas para figurar situaciones chistosas de todo tipo ${ }^{13}$. En estos casos, vemos que la gestualidad es la base para crear un meme de éxito del mismo modo que los gestos de las Pathosformel son los que garantizan su reutilización. En ambos casos, tanto en la reactivación de fórmulas de pathos como en los memes, la memoria es un concepto fundamental.

El término meme fue acuñado por el científico Richard Dawkins en 1976 en su libro El gen egoísta. Dawkins hablaba de los memes como elementos análogos a los genes. Si estos últimos se refieren al material genético que se transmite de una generación a otra, los memes aludirían a información cultural que se puede transmitir, o replicar, entre generaciones. Frente a la genética, enfocada en el estudio de los genes, la memética analizaría el material cultural que es capaz de ser transmitido entre generaciones:

«necesitamos un nombre para un nuevo replicador, un sustantivo que conlleve la idea de una unidad de transmisión cultural, o una unidad de imitación: Mimeme se deriva de una apropiada raíz griega, pero deseo un monosílabo que suene parecido a gen. Espero que mis amigos clasicistas me perdonen si abrevio mimeme y lo dejo en meme» (DAWKINS, 1997: 251).

La polémica idea de Dawkins considera que si los genes se propagan por medio de los espermatozoides o los óvulos, los memes lo hacen «al saltar de un cerebro a otro mediante un proceso que [...] puede llamarse de imitación» (DAWKINS, 1997: 251). El meme de internet adopta su nomenclatura del vocabulario de Dawkins ya que su forma de difundirse por la red es similar al proceso de transmisión cultural que el biólogo británico había estudiado. Si un meme se refiere a una unidad básica de información cultural que se transmite y propaga de generación en generación, el meme de internet debe su nombre a que la imagen se difunde y propaga entre los usuarios de manera muy similar, reproduciéndose y clonándose entre usuarios, ordenadores o smartphones.

Las ideas de Dawkins son muy semejantes a una serie de estudios llevados a cabo por Ewald Hering y Richard Semon a principios del siglo XX que influyeron de manera muy potente en el pensamiento de Aby Warburg. De ambos autores, Warburg tomó prestadas las expresiones mneme y engrama para referirse, respectivamente, a la memoria icónica social y a las fórmulas expresivas empleadas en representaciones de distintos tiempos, las Pathosformel. El ejemplo clásico de un engrama es el estudio de Warburg sobre el cuadro de Manet, Déjeneur su l'herbe, en el que señaló cómo el cuadro del pintor francés es deudor de un grabado de Marcantonio Raimondi que representa El juicio de Paris, que a su vez imita a un fragmento de Rafael en las estancias vaticanas, derivados todos ellos de sarcófagos clásicos. El engrama alude al esquema compositivo que permanece en la mneme social y que se reactiva en cada período en que se reutiliza. Dicho de otra manera, en la tradición de las imágenes, éstas perviven en la memoria social y se pueden descargar manteniendo su sentido original o modificándolo. El engrama es un residuo simbolizado de reacciones corporales primitivas por lo que la gestualidad que en él se contiene es fundamental para su continuidad y reactivación en el tiempo (GOMBRICH, 
culación y dispersión entre los usuarios

Los memes de internet funcionan como los engramas de Warburg pues su éxito descansa en aprovechar la gestualidad de una imagen para mantener o vaciar su sentido original y darle, así, nuevos significados. La gestualidad de una ménade, como se ha comentado, puede reconvertirse en una figura cristiana o en una manifestante en Cataluña. La gestualidad recogida en las fotografías de Alvarado y en el vídeo puede reconvertirse para figurar un contenido chistoso o satírico (Fig. 10). Hoy en día, los memes son la materia privilegiada para figurar emociones, condensar expresiones y sentidos por medio de la gestualidad (G. DE ANGELIS, 2016). El díptico fotográfico de Alvarado y el vídeo, al expresar las reacciones gestuales y emotivas de los asistentes a la proclamación de la independencia o ante los excesos policiales, fue un material idóneo para ser convertido en meme por el potencial gestual encerrado. Además, la viralidad que alcanzaron no sólo depende de la gestualidad contenida en ellos sino que, fotográficamente, contienen las claves para convertirse en una imagen icónica y, por lo tanto, en meme: son imágenes que pueden representar la totalidad del acontecimiento, fueron frecuentemente repetidas en la prensa y en televisión y están basadas en unas convenciones visuales que facilitan su simbolización y reutilización (BOUDANA, FROSH y COHEN, 2017).

Los usos que se hicieron de la imagen de Alvarado, así como cualquier meme que pudiéramos aportar en relación al procés, entran dentro de lo que Hito Steyerl ha denominado la «imagen pobre» (STEYERL, 2014: 33-48), un tipo de imagen propia de la contemporaneidad y de las posibilidades de la cultura visual 2.0 caracterizada por su mala calidad y por su condición dinámica. Es una imagen en la que priman las fáciles condiciones de accesibilidad y su cir- que la comparten: es una imagen que pierde materialidad pero que gana velocidad. Las imágenes pobres han creado una economía de imágenes de resistencia cuya circulación entre usuarios busca provocar debates como si fuese un panfleto, una hoja volante o una octavilla al convertir las redes y plataformas en que se difunden en un campo de batalla en el que librar la guerra de las imágenes de la que se daba cuenta al comienzo de estas líneas. Esas imágenes pobres descansan, a su vez, en la lógica de la apropiabilidad digital, una lógica que define cómo los usuarios se apropian de imágenes representativas de un acontecimiento y las modifican, alteran, distorsionan y ponen en circulación en esas mismas plataformas para expresar visiones satíricas (pero también políticas) de esos acontecimientos (GONDRA, G. DE ANGELIS, LÓPEZ DE MUNAIN y VIVES-FERRÁNDIZ, 2014: 111-135).

\section{A modo de conclusión}

El análisis de la fotografía de Alvarado y del vídeo Help Catalonia, junto a los memes que aprovecharon los rostros femeninos de gestos de pathos superlativos, ha permitido profundizar en el estudio de la cultura visual contemporánea generada en torno al procés. Por un lado, se ha señalado que ciertos recursos gestuales y emociones se han reactivado en imágenes de contextos políticos diferentes (el procés o la celebrificación de Obama) y que la comprensión de esa aparición está sustentada en cuestionarnos cuáles son las vicisitudes temporales de las emociones mediatizadas por imágenes. La posibilidad de dar un sentido o legibilidad en clave semiótica al empleo de viejas fórmulas visuales es desplazada por los paradigmas de la posmodernidad que ponen el acento en los efectos de presencia que tienen las imágenes del pasado (MOXEY, 2014) y en la bús- 
queda de marcos epistemológicos alternativos. Por otro lado, los memes de internet también operan con emociones mediatizadas por imágenes pues aprovechan el potencial gestual de las imágenes para reformularlas y dotarlas de nuevos sentidos para reforzar visiones políticas e identitarias del procés que se ponen en circulación en el espacio de la web 2.0.

1/ Se pueden consultar las propuestas en el Llibre blanc de la transició nacional de Catalunya: http://www.gencat.cat/eapc/revistes/RCDP/Documents_interes/RCDP_54/05_19Llibre_blanc_Sintesi.pdf [acceso: 23 de septiembre de 2018].

2/ https://www.theguardian.com/commentisfree/picture/2017/oct/27/martin-rowson-on-spain-catalonia-independence-power-struggle-cartoon [acceso: 15 de abril de 2018].

3/ https://twitter.com/Telegraph/status/914536533365051392/photo/1 [acceso: 15 de abril de 2018].

4/https://twitter.com/roweafr/status/914726155059646464/photo/1 [acceso: $15 \mathrm{de}$ abril de 2018].

5/ https://twitter.com/ferranmartin/status/914631167529426944 [acceso: 15 de abril de 2018].

6/ https://www.ara.cat/2017/10/10/Declaracio_Independencia_amb_logo_-1.pdf [acceso: 15 de abril de 2018].

7/ http://cadenaser.com/ser/2017/10/10/politica/1507663485_341695.html [acceso: 15 de abril de 2018].

8/ La posición del fotógrafo y el hecho de que los asistentes al acto estuvieran contemplando las pantallas gigantes dispuestas en la calle condicionan que la imagen esté tomada con un picado que enfatiza el sentido simbólico de la misma.

9/ https://www.youtube.com/watch?v=KLCoW_GiXAs [acceso: 21 de abril de 2018].

10/ https://www.flickr.com/photos/obamawhitehouse/ [acceso: 23 de abril de 2018].

11/ https://www.flickr.com/photos/obamawhitehouse/8341815158/ https://www. flickr.com/photos/obamawhitehouse/6599542705/ https://www.flickr.com/photos/ obamawhitehouse/6599499635/ [acceso: 23 de abril de 2018].

12/ El paso más decidido en la espectacularización de la imagen de Obama es su participación en un vídeo que se muestra en la cuenta oficial de la Casa Blanca en YouTube en el que se ha prestado a confundir su papel de presidente con el del actor Daniel Day-Lewis. El director Steven Spielberg comenta que tras el éxito de la película Lincoln (2012) decidió dirigir la película Obama, proyecto para el que tuvo que decidir quién interpretaría el papel del presidente. Los campos de la realidad y la ficción se confunden ya que el actor elegido por el director para representar el papel es Daniel Day-Lewis, es decir, el mismo que había hecho de Lincoln. La sorpresa estalla cuando el vídeo muestra al propio Barack Obama interpretando a Daniel Day-Lewis interpretando a Barack Obama. En el vídeo, Obama, rotulado como Daniel Day-Lewis, explica el proceso que siguió para actuar como el presidente Obama, trabajando el acento, los gestos, sus motivaciones, etc., todo adornado con la banda sonora original de la película Lincoln. La representación dentro de la representación alcanza su máximo apogeo cuando Obama, al final del vídeo, asegura que es Daniel Day-Lewis. Se puede ver el vídeo en el siguiente enlace: https://www.youtube.com/ watch?v=ZyU213nhrh0\&list=TL09a694LmL_WsXIpJcGvkqoKEzL175UNj [acceso: 23 de abril de 2018].

13/ Un compendio de estos memes en: https://www.buzzfeed.com/guillermodelpala- 
cio/video-help-catalonia?utm_term=.gqDmV2NyV\#.vcawGkZLG

http://www.publico.es/tremending/2017/10/11/twitter-los-mejores-me-

mes-de-la-casi-independencia-de-catalunya/

https://vozlibre.com/actualidad/la-independencia-los-8-segundos-las-mejo-

res-reacciones-las-redes-5284/,https://verne.elpais.com/verne/2017/10/10/articulo/1507653719_231546.html [acceso: 15 de abril de 2018].

\section{Referencias bibliográficas}

BAL, Mieke (2016). Tiempos trastornados: análisis, historias y políticas de la mirada. Madrid: Akal.

BARASCH, Moshe (1999). Giotto y el lenguaje del gesto. Madrid: Akal.

BIALOSTOCKI, Jan (1973). Estilo e iconografía: contribución a una ciencia de las artes. Barcelona: Barral.

BOEHM, Gottfried (2011). ¿Más allá del lenguaje? Apuntes sobre la lógica de las imágenes. GARCÍA VARAS, Ana (ed.), Filosofía de la imagen (pp. 87-106). Salamanca: Ediciones Universidad de Salamanca.

BOUDANA, Sandrine; FROSH, Paul y COHEN, Akiba A. (2017). Reviving icons to death: when historical photographs become digital memes. Media, culture and society, n. 39/8, pp. 1-21.

CABELLO, Gabriel (2017). Entre historia del arte y práctica de las imágenes: aura y dolor de reminiscencias en Georges Didi-Huberman. Anthropos, 247, pp. 146-163.

CANO BUESO, Juan (2017). Cataluña en su laberinto. Valencia: Tirant.

DAWKINS, Richard (1997). El gen egoísta. Las bases biológicas de nuestra conducta. Barcelona: Salvat.

DÍAZ MARROQUÍN, Lucía (2008). La retórica de los afectos. Kassel: Reichenberger.

DIDI-HUBERMAN, Georges (2007). La invención de la histeria. Charcot y la iconografía fotográfica de La Salpêtrière. Madrid: Cátedra.

DIDI-HUBERMAN, Georges (2013). La imagen superviviente. Historia del arte y tiempo de los fantasmas según Aby Warburg. Madrid: Abada.

DIDI-HUBERMAN, Georges (2017). Pueblos en lágrimas, pueblos en armas. El ojo de la historia, 6. Santander: Shangrila.

DIDI-HUBERMAN, Georges (2017). Insurreccions. Barcelona: Museu Nacional d'Art de Catalunya.

FORTI, Steven; GONZÁLEZ I VILLALTA, Arnau; UCELAY-DA CAL, Enric (2017). ¿Qué es el procés? Sopesar los cambios en la política catalana entre 2006 y 2017. FORTI, Steven; GONZÁLEZ I VILLALTA, Arnau; UCELAY-DA CAL, Enric (eds.), El proceso separatista en Cataluña. Análisis de un pasado reciente (2006-2017) (pp. 3-6). Granada: Editorial Comares.

GOMBRICH, Ernst (1992). Aby Warburg. Una biografía intelectual. Madrid: Alianza.

GONDRA, Ander; G. DE ANGELIS, Marina; LÓPEZ DE MUNAIN, Gorka; VIVES-FERRÁNDIZ, Luis (2014). Cuando despertó, el elefante todavía estaba allí. La imagen del rey en la cultura visual 2.0. Barcelona: Sans Soleil Ediciones.

G. DE ANGELIS, Marina (2016). Del Atlas mnemosyne a GIPHY: La supervivencia de las imágenes en la era del GIF. e-imagen Revista 2.0, n. 3.

KELLNER, Douglas (2011). Cultura mediática. Estudios culturales, 
identidad y política entre lo moderno y lo posmoderno. Madrid: Akal.

MARTÍN PRADA, Juan (2012). Prácticas artísticas en internet en la época de las redes sociales. Madrid: Akal.

MITCHELL, W.J.T. (2013). Cloning terror. The war of images from 9/11 to present day. Chicago: The Chicago University Press.

MOXEY, Keith (2014). El tiempo de lo visual. La imagen en la historia. Barcelona: Sans Soleil.

OLIVA, Mercè; PÉREZ-LATORRE, Oliver; BESALÚ, Reinald (2015). Celebrificación del candidato. Cultura de la fama, marketing electoral y construcción de la imagen pública del político. Arbor. Ciencia, Pensamiento Y Cultura, 191(775), a270.

PINOTTI, Andrea (2016). La replica non indiferente. Mosse di iconología política all'epoca dell'internet-meme. GUASTINI, Daniele y ARDOVINO, Adriano (eds.), I percorsi dell'immaginazione. Studi in onore di Pietro Montani (pp. 417-431). Cosenza: Luigi Pellegrini Editori.

RIPA, Cesare (1996). Iconología. Madrid: Akal.

SÁNCHEZ-CUENCA, Ignacio (2018). La confusión nacional, La democracia española ante la crisis catalana. Madrid: Los libros de la catarata.

STEYERL, Hito (2014). Los condenados de la pantalla. Buenos Aires: Caja Negra.

STOICHITA, Victor (1996). El ojo místico. Visión y pintura religiosa en el siglo de oro español. Madrid: Alianza.

VIVES-FERRÁNDIZ, Luis (2012). Yes we Flickr! Imágenes del poder en la era de la postfotografía. MÍNGUEZ, Víctor (ed.), Las artes y la arquitectura del poder (pp. 501-516). Castellón: Universitat Jaume I.

VIVES-FERRÁNDIZ, Luis (2014). La gran pantalla del mundo. La lógica barroca del capitalismo de ficción. Caracteres. Estudios culturales y críticos de la esfera digital, n. 3/1, pp. 179-200.

WARBURG, Aby (2010). Atlas Mnemosyne. Madrid: Akal.

WIND, Edgar (1937). The Maenad under the cross. Comments on an observation by Reynolds. Journal of the Warburg Institute, n. 1, pp. 70-71.

Cómo citar VIVES-FERRÁNDIZ SÁNCHEZ, Luis (2019). Pathos en Cataluña: las políticas de las imágenes en la era de los memes. Comparative Cinema, Vol. VII, No. 12, pp. 150-161. DOI: 10.31009/cc.2019. v7.i12.02 